Article

\title{
Inter-Campus Sharable Potential of Hardware Educational Resources in A University Town: Connotation, Determination Method and A Case Study
}

\author{
Yali Zhang ${ }^{1,2, *}$, Huihui Zhu ${ }^{1}$, Bo Mu ${ }^{1,+}$, Xiaojian Zhang ${ }^{3}$ and Xuerong Cui ${ }^{3}$ \\ 1 Institute of Resources and Environment, Henan Agricultural University, 95 Wenhua Road, \\ Zhengzhou 450002, China; zhuhuihui2020@163.com (H.Z.); bomu@henau.edu.cn (B.M.) \\ 2 Henan Engineering Research Center of Land Consolidation and Ecological Restoration, 95 Wenhua Road, \\ Zhengzhou 450002, China \\ 3 College of Animal Science and Veterinary Medicine, Henan Institute of Science and Technology, \\ Easter of Hualan Road, Xinxiang 453003, China; zxj9109@hist.edu.cn (X.Z.); cuixuerong888@163.com (X.C.) \\ * Correspondence: skyali@henau.edu.cn; Tel.: +86-371-63555504 \\ + This author contributed equally to this work.
}

Received: 8 January 2020; Accepted: 18 February 2020; Published: 21 February 2020

check for updates

\begin{abstract}
Sharing educational resources (ERs) among campuses in a university town (UT) could avoid the waste or repeated construction of ERs, which is beneficial to the sustainable utilization of resources. For hardware educational resources (HERs) greatly attached to land resources, whether they have surplus shareable potential is the key factor relating to inter-campus sharing. However, there is a serious lack of definition and quantitative research on HERs' shareable potential. Based on the correlation between land resource utilization and HER sharing, we firstly defined the connotation of inter-campus sharable potential of HERs (ISPHERs), put forward its calculation method and carried out a case study in Longzi Lake UT of Zhengzhou City, Henan province, China. The results show that: (1) ISPHERs could be defined from the perspective of "the best utilization degree" which mainly depended on the utilization and development gap between the present area value and the possible most intensive one under certain conditions; (2) based on the area quota and the students' number, the ISPHERs was calculated by the Delphi and multi-factor model methods; (3) the case study in Longzi Lake UT of Zhengzhou City, Henan province, China showed that the comprehensive ISPHERs was high in the south and low in the north, and the libraries and canteens in five colleges and universities mainly providing vocational skills training were insufficient. If all the 11 campuses could freely share HERs, there would be an overall surplus of the five kinds of HER (i.e., classroom, laboratory, library, indoor sports room and canteen). The comprehensive management framework should include sustainable concept guidance, cooperation system construction, planning control, benefit adjustment and technological innovation, etc.
\end{abstract}

Keywords: hardware educational resources; inter-campus sharable potential; intensive use of resources; sustainable development; management framework; University Town

\section{Introduction}

With the continuous progress of the social economy, the demand for resources is increasing, and the concept of the sustainable use of resources has become more and more popular in recent decades. The sustainable utilization of resources involves making full, rational, intensive and efficient use of existing resources, and continuously developing new alternative resources to ensure the sustainable 
utilization by human beings [1]. With the expansion of enrollment rate in colleges and universities, the number of university students has increased dramatically in recent years in some developing countries, such as India and China [2,3]. There is no doubt that this will put great pressures on the limited educational resources (ERs). The inter-campus sharing of educational resources (ISERs) in colleges and universities can make up for this shortage to a degree, and avoid waste or repeated construction of ERs. ISERs refers to the cooperative utilization of hardware educational resources (HERs) and software educational resources among different campuses in a certain region. HERs are mainly the school buildings, such as library, classroom, laboratory and sports room, etc.; software educational resources are mainly the course setting, level of teachers, credit identification, etc. [4,5]. Although it will bring some management challenges, such as benefit coordination, intellectual property protection and campus security, ISERs is the best way to improve the efficiency of running universities with the existing educational input, and is beneficial to the sustainable utilization of resources [6,7]. In order to promote ER sharing, to attract and gather higher education institutions and high-level experts, to strengthen social relations or develop social networks, etc., many university towns (UTs), campus towns, university districts, or university communities, etc., have emerged in the world [8-10]. They are all called UTs in this study. From the end of the 1990s, China has built more than 100 UTs, such as the East UT of Beijing City, the Songjiang UT of Shanghai City, the Shenzhen UT, and the Yuelu Mountain UT of Changsha City, etc. [11,12].

Because of the concentration of colleges and universities, UTs have the natural advantage of sharing ERs among campuses. The core of UT construction in China is that each school is relatively independent, and their ERs can be sustainably shared with each other [12]. However, most of the existing studies of ISERs have overlooked a very vital factor. For each independent campus in a UT, are its ERs abundant, especially its HERs greatly attached to land resources? Can they meet the needs of its own operation and development? Are there any spare ERs to share? That is to say, the property rights of ERs are usually private. If there is surplus after satisfying its own use, it can be possibly provided to other consumers through unified management. In other words, whether inter-campus sharing can be realized mainly depends on whether the ERs of various campuses have the potential to supply. For some software educational resources (i.e., teacher level, lectures, electronic books and teaching management etc.), many have begun to be shared online through new world university cities, network education communities, education blogs, campus network platforms, etc. [13-15]. This breaks through the limitations of time and place, and usually has unestimable sharing potential under certain conditions. However, for HERs existing as an immovable entity (such as classrooms, laboratories, libraries, gymnasiums, academic exchange centers and halsl, etc.), they are the key assessment indexes in various audits, and the results of a great deal of manpower, material and financial resources for a long time. They are competitive; that is, a person using these resources will reduce others' consumption.

Potential is the difference between the current level and the optimal level of things that can be achieved under certain conditions [16]. In theory, any competing resources have potential for development and utilization. At present, studies on resources' potential have mainly focused on mineral resources [17], tourism resources [18], water resources [19], and land resources [20], etc. Both qualitative and quantitative research, either theoretical or practical, is relatively mature. However, literature retrieval shows that there are few studies on the potential of ERs, and there is a particular lack of connotation definition and quantification research. The existing studies emainly discussed the opportunities and possibilities for ER development and utilization [21,22]. The potential of ERs is not used as a term to define their meaning and quantification methods.

Longzi Lake UT of Zhengzhou City has the most campuses and enrollment students in Henan Province, and usually has the most applicants for the college entrance examination in China (with more than 1 million applicants in 2019). The colleges and universities are connected by roads and green belts, with convenient transportation (i.e., bus around the lake and shareable bikes) and natural advantages of resource sharing. On 7 January 2019, according to the principles of "equality and mutual benefit, complementary advantages, resources sharing and win-win cooperation", Henan Agricultural 
University (HAU), North China University of Water Resources and Electric Power (NCUWREP), Henan University of Economics and Law (HUEL), and Zhengzhou University of Aeronautics (ZUA) began to establish a sharing mechanism of ERs, and will gradually implement mutual selection and recognition of courses, mutual employment of teachers, etc. [23]. This is the first ER sharing among colleges and universities in Henan Province, China. Although this is mainly about software educational resource sharing, it will certainly promote HER sharing in Longzi Lake UT in the future.

Therefore, the main purposes of this study are: (1) to define the connotation of inter-campus shareable potential of HERs (ISPHERs) in a UT from a sustainable perspective on both the intensive use of land resources and ERs, (2) to put forward a calculation method of ISPHERs which could provide the quantitative information for the ISPHERs' for every campus; (3) to present a case study in Longzi Lake UT, Zhengzhou City, Henan Province, China which might verify the methods' feasibility. This paper also develops a comprehensive guarantee system which is beneficial to break the "wall" among campuses and to promote HER sharing among them. This study might simultaneously promote the intensively sustainable use of educational land resources and HERs, reduce the educational cost, and enhance the sustainable development of higher education in regions with centralized colleges and universities.

\section{Literature Review and Research Hypothesis}

UTs originated in the 17th century, when a group of scholars expelled from France lived in Oxford, a city with academic freedom. As a result, a royal-funded college began to be built. Independent colleges were scattered throughout Oxford, resulting in the gradual formation of Oxford UT [24]. There are two kinds of UT evolution-one is the natural development of a UT, and the other is a planned and constructed one. In the former, with the development of the social economy and higher education industry in one place, the scales of one or more universities increased, a larger and larger population gathered in or around the university and engaged in tertiary industry, and then a town gradually formed [12]. Most of the foreign UTs belong to the former [12]. The more famous ones are Cambridge UT, Gottingen UT, California UT, and so on. For the later ones, mainly with the rapid development of higher education after World War I, they were usually co-established by the State, the local government, some institutions and enterprises, etc., such as the City of Tsukuba University in Japan and the Missouri University in the United States [25-27]. Most foreign UTs have gone through a long developing period and are relatively mature now. The current research mainly focuses on ERs' integration and interactive development between the university and community [28], the development of higher education [25], the comparison between UTs and other cities [29], and the characteristics of UTs [30], etc. There are some world-famous multi-functional towns, such as Silicon Valley in the United States, Cambridge University City, British Silicon Marsh, etc., which are highly unified in teaching, technology development, industrial management and community services $[13,24,26]$. Foreign inter-campus cooperation also has a long history, such as that in Claremont Colleges of the United States, which originated as early as 1925, which enabled students to choose courses across schools, share books and materials, and share information technology, etc. [31].

The UTs in China usually belong to the planned and constructed type. Their development period has not been going for long, such that their main functions and structures are relatively in the initial period [12]. The existing studies on ISERs mainly focused on the following aspects: survey of sharing status [4,32], sharable contents [11,33], obstacles and reasons in sharing [34,35], measures to achieve sharing [5], etc. At present, it is generally believed that ISER in most UTs in China is not very efficient $[4,11,35]$. According to the survey of Guan [36] in Fuzhou UT, Fujian Province, China, less than $1 \%$ of students have used the sports facilities in the other campuses; $59 \%$ of the students have gone to the other restaurants and student streets, but the average annual rate is less than $1 \%$. This will unavoidably lead to lower use efficiency, repeated construction and serious waste of ERs. This is not only contrary to the sharing concept in UT, nor is it consistent with the aim of the sustainable use of resources. On one hand, it is due to the different government of each campus. On the other hand, 
the free sharing concept in UTs is not very popular. Existing sharing practices focus mainly on libraries, teaching equipment, teacher resources, sports facilities, and so on [37-39]. The methods of sharing focus on teaching consortiums, cooperative school-running community, and network management platform, etc. $[14,40,41]$. In terms of the sharing guarantee mechanism, it includes updating the school-running philosophy, improving the security policies, improving the basic conditions and overcoming the sharing limitations, etc. [39,42,43].

At present, many colleges and universities of most UTs in China mainly focus on their HERs management and development, rather than the inter-campus sharing that requires more coordination and effort $[12,32,36]$. Land resources are the direct carriers of various HERs, and are the important index to determine the scale and capacity of a campus. In recent years, due to lack of effective planning and control of UT establishment, some local governments have sought to promote the development of new urban areas through them, and many colleges and universities blindly pursue a large scale-the scale of some new campuses in UTs is expanding and the educational land resources are out of control to a degree. There are a lot of negative reports about these phenomena $[15,42,44]$. In order to fully understand the situation of land use in colleges and universities, the Ministry of Land and Resources in China conducted an investigation and intensive utilization evaluation of educational land resources in six colleges and universities (i.e., Peking University, China University of Geosciences (Beijing), Jilin University, Zhejiang University, Tianjin normal University and Nanjing normal University) in 2011, and promulgated the Technical Guide for Intensive Use Evaluation of Educational Land in Colleges and Universities later [45]. Then the intensive evaluation of educational land resources in typical cities and provinces was carried out in the following years. Compared with HERs, the intensive use of educational land resources has more mature research, including theory, evaluation methods and management measures, etc.

Our research is based on the close relationship between educational land resources and HERs. The quantity, development and utilization of the former greatly determines the abundance or shortage of HERs. In other words, the building area of HERs determines whether they have sharable potential. To promote the intensively sustainable use of these two resources for campuses with scarce resources, they can search for alternative resources from the others with surplus. For resource-rich campuses, they can provide the surplus resources to other needy ones. This is the principle required to realize HER sharing among campuses. Therefore, the connotation of ISPHERs in a UT could be based on the intensive use of resources, and it could be quantified according to the building area quotas of HERs.

\section{Connotation of ISPHERs in A UT}

According to the Land Administration Law of the People's Republic of China [46], colleges and universities acquire the right to use educational land resources through allocation, and use them to build school buildings [47]. Educational land resources are the carriers of HERs. To improve talent training, scientific research output and social service in colleges and universities, one should pay more attention to optimizing the land use structure, and to improving the land use degree and intensity $[10,45,47]$. However, because the total land area is definite, the enrollment is limited, and the school buildings have been planned and built, this inner approach of intensive use will not really work in the short term. For the regions with concentrated campuses where the school buildings are close to each other, such as in a UT, it is advised to establish the concept of sharing educational land resources, and tap their inter-campus potential, so as to make the limited educational land resources serve the local higher education more effectively and sustainably [48].

Therefore, to quantify whether HERs of a campus have shareable potential, we can draw on the assessment of the intensive use of educational land resources and define the ISPHERs from the sustainable perspective of "the best utilization degree". For the land area of school buildings in one campus, after ensuring their own demands during a certain period are met, there is still excess to provide to the others. This mainly depends on the gap between HERs' current area and the possible most intensive one. Therefore, based on the HERs' appropriate area quota and the number of 
consumers (i.e., students and faculty), we can calculate the difference between the actual area and the suitable one of each HER in a campus. Then, it can be judged whether a campus has some surplus HERs, and whether it can provide some HERs or needs to be supplied. Lastly, both the potential of inter-campus sharing of each HER in one campus and that in the UT as a whole can be quantified.

\section{Methodology}

\subsection{Data Collection}

By means of the interpretation of remote sensing images, data collection, field survey, department survey, literature search and other means, the following data and information of colleges and universities in the study area were obtained. Firstly, data and maps of land use, school building status and planning which include area of various types of educational land resources, building base area and building area, allocation ratio of land area for multi-purpose school buildings, and plot ratio, etc. were obtained [45]. Secondly, the total number of faculty, students and personnel training in the past five years was calculated. Thirdly, strategy planning of school development, campus function orientation and annual work reports in the last five years, and other relevant data, were obtained.

\subsection{HERs that Can Be Shared among Campuses}

Through field surveying and comparative analysis, the types of sharable HER were determined by considering the types of colleges and universities, disciplinary differences, management levels, technical conditions, natural factors, planning restrictions and development requirements, etc. These included dormitories, classrooms, laboratories, libraries, indoor sports, halls, canteens, etc. Because of the private rights or administrative levels, it is difficult to share teachers' residential rooms and administrative offices. These school buildings are not involved in this study for the time being.

\subsection{Calculation of ISPHERs}

(1) Determination the area quota of per student for each HER

The area quotas per student for each HER are mainly in accordance with the national or local building standard. Meanwhile, these quotas can be adjusted to the relevant local planning, regional topography, climate building zoning and other factors, combined with the actual situation of colleges and universities.

(2) Calculation of the shareable potential

Whether there is a shareable potential is determined by Equation (1):

$$
R_{i}=S_{i} / B_{i}
$$

where $i$ is a kind of HERs, $R_{i}$ is rate over area quota, $S_{i}$ is the current area per student ( $\mathrm{m}^{2}$ per student), and $B_{i}$ is the area quota per student $\left(\mathrm{m}^{2}\right.$ per student).

For the indicators less than or equal to the area quota, they indicate that there is no shareable potential. If $R_{i}<0$, it means this kind of HER cannot meet its own needs and resources should be provided from other campuses. For $R_{i}>0$, it is considered that there is shareable potential.

We calculate the area potential of HERs that can share or need to be provided by Equation (2):

$$
\Delta S_{i}=S_{i}-B_{i} \times Q_{i}
$$

where $\Delta S_{i}$ is the shareable area potential ( $\mathrm{m}^{2}$ per student), $Q_{i}$ is the number of students on the campus. If $\Delta S_{i}>0$, it means that there is shareable potential. If $\Delta S_{i} \leq 0$, it means that there is no shareable potential. The HERs should be provided from other campuses if $\Delta S_{i}<0$. 
The student number potential of HERs $\left(\Delta Q_{i}\right)$ that can share or need to be provided are calculated by Equation (3).

$$
\Delta Q_{i}=\Delta S_{i} / B_{i}
$$

The total shareable area potential in a UT $(\Delta S)$ is as follows:

$$
\Delta \mathrm{S}=\sum_{i=1}^{n} \Delta S_{i}
$$

The total shareable student potential in a UT $(\Delta \mathrm{Q})$ is as follows:

$$
\Delta \mathrm{Q}=\sum_{i=1}^{n} \Delta Q_{i}
$$

\subsection{Calculation of the Potential Grade}

(1) Weight determination

The index weight $(\mathrm{Wi})$ is determined by the Delphi method [49], and the weights of the evaluation buildings are between 0 and 1, and their sum is 1 . We calculate the weight value according to Equation (6).

$$
W_{i}=\frac{\sum_{j=1}^{m} E_{i j}}{m}
$$

where $w_{i}$ is the weight of a kind of HER $i$; $E_{i j}$ is the score of HER $i$ from the expert $j ; m$ is the total number of experts.

Experts participating in the scoring should be familiar with the use of educational land resources and the sharing of ERs, such as the government officers in UTs and campuses, teachers in campuses, and technical personnel in education government, land resources and building planning, etc. The number of experts is generally from 15 to 30 . The topics are on the impact and importance of each HER on a campus' overall sharable potential, which needs to be assigned a certain number between 0 and 1 . The experts should independently score without mutual consultation. From the second round of scoring, the results of the previous one should be referred to. There should be at least 3 rounds of scoring.

(2) The comprehensive index and grade of ISPHERs

The potential index for HER $i\left(K_{i}\right)$ is determinated by Equation (7).

$$
K_{i}=\Delta S_{i} / S_{i}
$$

We calculate the comprehensive index of area potential (K) using Equation (8).

$$
K=\sum_{i=1}^{n} K_{i} \times W_{i}
$$

(3) Classification of potential grades

The natural break point method is used to determine the classification of potential grades (Table 1). 
Table 1. The comprehensive index $(\mathrm{K})$ and grade of sharable area potential for hardware educational resources (HERs).

\begin{tabular}{|c|c|c|c|c|}
\hline Sharable Types & Potential Status & $\mathbf{K}$ & Sharable Grade & Characteristics \\
\hline \multirow{5}{*}{ I } & \multirow{5}{*}{$\begin{array}{l}\text { More than the standard } \\
\text { and with surplus to } \\
\text { provide. }\end{array}$} & $\mathrm{K} \geq 0.8$ & $\mathrm{I}-\mathrm{i}$ & $\begin{array}{l}\text { With higher sharable } \\
\text { potential }\end{array}$ \\
\hline & & $0.60 \leq \mathrm{K}<0.80$ & II-ii & With high sharable potential \\
\hline & & $0.40 \leq \mathrm{K}<0.60$ & II-iii & $\begin{array}{l}\text { With medium sharable } \\
\text { potential }\end{array}$ \\
\hline & & $0.20 \leq \mathrm{K}<0.40$ & II-iv & With low shareable potential \\
\hline & & $0<\mathrm{K}<0.20$ & II-v & $\begin{array}{c}\text { With lower shareable } \\
\text { potential }\end{array}$ \\
\hline II & $\begin{array}{l}\text { The same as the standard } \\
\text { and without surplus. }\end{array}$ & $K=0$ & II & $\begin{array}{l}\text { No shareable potential, no } \\
\text { shareable need }\end{array}$ \\
\hline \multirow{5}{*}{ III } & \multirow{5}{*}{$\begin{array}{l}\text { Less than the standard } \\
\text { and need to be provided. }\end{array}$} & $-0.2 \leq \mathrm{K}<0$ & III-i & With lower shareable need \\
\hline & & $-0.40 \leq \mathrm{K}<-0.20$ & III-ii & With low shareable need \\
\hline & & $-0.6 \leq \mathrm{K}<-0.40$ & III-iii & $\begin{array}{l}\text { With medium shareable } \\
\text { need }\end{array}$ \\
\hline & & $-0.8 \leq \mathrm{K}<-0.6$ & III-iv & With high shareable need \\
\hline & & $\mathrm{K}<-0.8$ & III-v & With higher shareable need \\
\hline
\end{tabular}

\section{Study Area and Data Source}

\subsection{Study Area}

Longzi Lake UT is in the east of Zhengzhou City, Henan Province, China. It is planned as an educational and scientific research region, which is composed of Longzi Lake Project and new campuses of 15 colleges and universities [50]. The former covers an area of about $2.73 \mathrm{~km}^{2}$. It consists of a lake and some public facilities such as shopping malls, supermarkets, theatres and academic centers. There are 12 campuses around Longzi Lake, covering an area of about $8.34 \mathrm{~km}^{2}(34.7898-34.7991 \mathrm{~N}$ and 113.7964-113.8076 E). They are HUEL, NCUWREP, ZUA, HAU, Henan Institute of Judicial and Police Officers (HIJPO), Henan University of Chinese Medicine (HUCM), Henan Polytechnic (HP), Henan Institute of Economics and Trade (HIET), Henan Radio \& Television University (HRTU), Henan Finance University (HFU), Henan University of Animal Husbandry and Economy (HUAHR) and Henan Police College (HPC) (Figure 1).
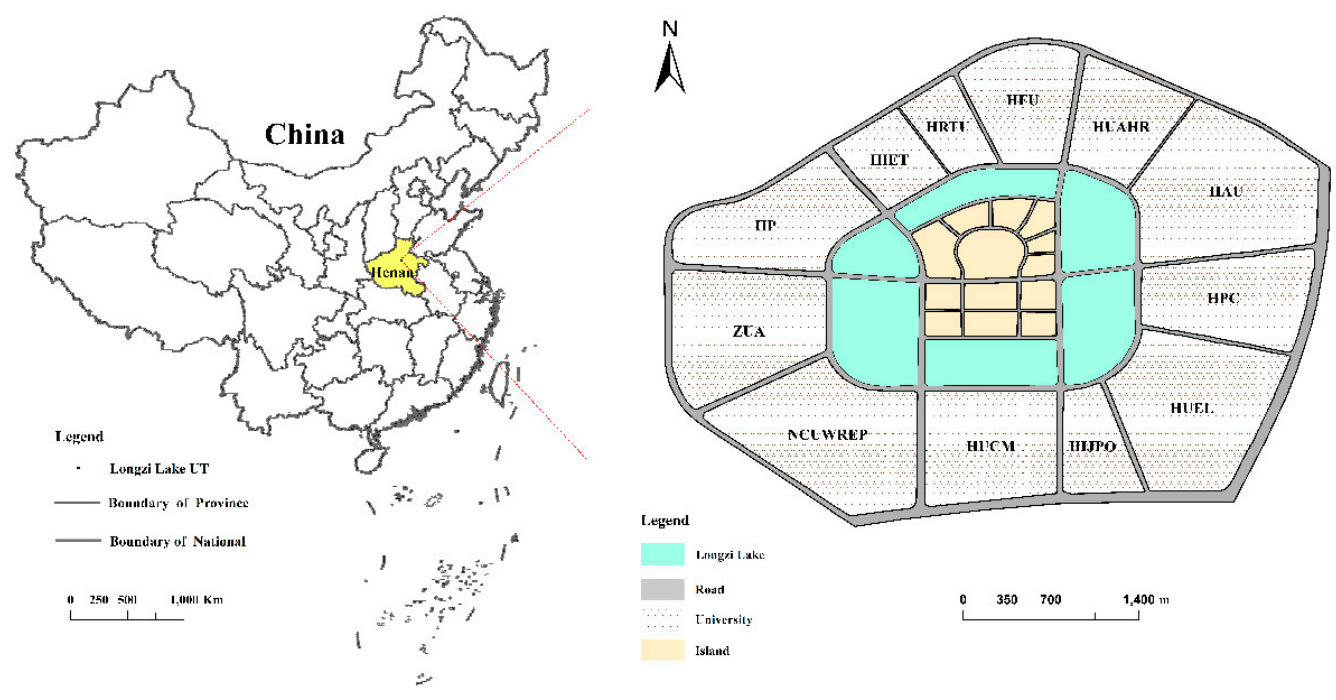

Figure 1. Location and layout of colleges and universities in Longzi Lake University Town (UT). 
In the above-mentioned 12 campuses, most of them were settled and put into operation in 2005 or 2006, while the four campuses of HAU, HUAHR, HUEL and HIET were founded in 2010 or 2011. Only HIJPO's campus was put into use in 2016, and some of the buildings have not been built at all. HIJPO covers an area of $0.33 \mathrm{~km}^{2}$, is particularly focused on the training of higher judicial and police officers. Because its unused land is much greater and has had construction fences for a long time, it is difficult to share HERs now. Therefore, we chose the other 11 colleges and universities with relatively mature educational facilities to carry out the ISPHERs research.

\subsection{Data Source}

The data and map of land use were mainly obtained from the interpretation of remote sensing images through Google Earth and field investigation. The area of various types of educational land resources, building base areas and building areas, the allocation ratio of land area for multi-purpose school buildings, and plot ratio, etc., were mainly obtained from field investigation and the management departments of campuses. The number and kind of students, and subject composition, were mainly taken from school's annual reports and management departments. The strategy planning of school development, and campus function orientation, etc., were mainly obtained from the management departments and network. The data are from up to May 2018.

\section{Results}

\subsection{The Sharable HERs and Their Area Quota of Per Student in Longzi Lake UT}

According to the availability of data and the sharable feasibility analysis, the sharable HERs in the study area mainly include classrooms, laboratories, libraries, indoor sports classrooms and canteens. Because there are no local standards about the area index of HERs in Henan province, the area quota per student for each HER is mainly based on the Area Index of Building Planning in Colleges and Universities (Standard 191-2018, in brief) approved by the Ministry of Education of the People's Republic of China [51], as shown in Table 2. The area for each school building in this standard and the following study is the building area-that is, the product of the outer dimensions of length and width of the building is multiplied by the building floor. The laboratories and libraries for graduate students are different from those for undergraduate students, so the subsidy index should be added to the average floor area of undergraduate students (Table 3). 
Table 2. Area quota values of school buildings (classroom, laboratory, library, indoor sports room and canteen).

\begin{tabular}{|c|c|c|c|c|c|c|c|c|c|c|c|c|c|c|c|}
\hline \multirow[b]{2}{*}{$\begin{array}{l}\text { School } \\
\text { Classes }\end{array}$} & \multirow[b]{2}{*}{$\begin{array}{l}\text { Discipline } \\
\text { Structure }\end{array}$} & \multirow[b]{2}{*}{$\begin{array}{l}\text { Students } \\
\text { Scale }\end{array}$} & \multicolumn{5}{|c|}{ Area Quota ( $\mathrm{m}^{2}$ Per Student) } & \multirow[b]{2}{*}{ School Classes } & \multirow[b]{2}{*}{$\begin{array}{l}\text { Discipline } \\
\text { Structure }\end{array}$} & \multirow[b]{2}{*}{$\begin{array}{l}\text { Students } \\
\text { Scale }\end{array}$} & \multicolumn{5}{|c|}{ Area Quota $\left(\mathrm{m}^{2}\right.$ Per Student) } \\
\hline & & & Classroom & Laboratory & Library & $\begin{array}{l}\text { Indoor } \\
\text { Sports } \\
\text { Room }\end{array}$ & Canteen & & & & Classroom & Laboratory & Library & $\begin{array}{l}\text { Indoor } \\
\text { Sports } \\
\text { Room }\end{array}$ & Canteer \\
\hline \multirow{3}{*}{$\begin{array}{l}\text { Comprehensive } \\
\text { university (1) }\end{array}$} & \multirow{3}{*}{$\begin{array}{l}\text { Grammar } 60 \% \text {, } \\
\quad \text { SE } 40 \%\end{array}$} & 5000 & \multirow{3}{*}{2.83} & 5.43 & 2.02 & 1.11 & 1.30 & \multirow{3}{*}{ Medical college } & \multirow{3}{*}{$\begin{array}{l}\text { Medicine } 90 \% \text { and } \\
\text { grammar } 10 \%\end{array}$} & 5000 & \multirow{3}{*}{2.75} & 7.40 & 2.00 & 1.11 & 1.30 \\
\hline & & 10,000 & & 4.63 & 1.74 & 1.37 & 1.25 & & & 10,000 & & 6.60 & 1.71 & 1.37 & 1.25 \\
\hline & & 20,000 & & 4.00 & 1.54 & 1.05 & 1.20 & & & 20,000 & & 6.36 & 1.50 & 1.05 & 1.20 \\
\hline \multirow{3}{*}{$\begin{array}{l}\text { Comprehensive } \\
\text { university (2) }\end{array}$} & \multirow{3}{*}{$\begin{array}{c}\text { SE } 60 \%, \\
\text { grammar } 40 \%\end{array}$} & 5000 & \multirow{3}{*}{2.88} & 6.75 & 2.00 & 1.11 & 1.30 & \multirow{3}{*}{$\begin{array}{l}\text { Finance, political } \\
\text { and law colleges }\end{array}$} & \multirow{3}{*}{ Grammar 100\% } & 5000 & \multirow{3}{*}{2.66} & 1.54 & 2.02 & 1.11 & 1.30 \\
\hline & & 10,000 & & 5.76 & 1.71 & 1.37 & 1.25 & & & 10,000 & & 1.26 & 1.74 & 1.37 & 1.25 \\
\hline & & 20,000 & & 5.02 & 1.50 & 1.05 & 1.20 & & & 20,000 & & 1.01 & 1.54 & 1.05 & 1.20 \\
\hline \multirow{3}{*}{$\begin{array}{c}\text { Normal and } \\
\text { nationalities } \\
\text { university }\end{array}$} & \multirow{3}{*}{$\begin{array}{c}\text { Grammar } 45 \% \text {, } \\
\text { SE } 40 \% \text {, art } \\
10 \% \text {, sports } 5 \%\end{array}$} & 5000 & \multirow{3}{*}{2.88} & 5.66 & 2.02 & 1.11 & 1.30 & \multirow{3}{*}{$\begin{array}{c}\text { Foreign } \\
\text { language college }\end{array}$} & \multirow{3}{*}{$\begin{array}{l}\text { Foreign language } \\
90 \% \text {, grammar } 10 \%\end{array}$} & 5000 & \multirow{3}{*}{3.30} & 1.54 & 2.02 & 1.11 & 1.30 \\
\hline & & 10,000 & & 4.77 & 1.74 & 1.37 & 1.25 & & & 10,000 & & 1.26 & 1.74 & 1.37 & 1.25 \\
\hline & & 20,000 & & 4.02 & 1.54 & 1.05 & 1.20 & & & 20,000 & & 1.01 & 1.54 & 1.05 & 1.20 \\
\hline \multirow{3}{*}{$\begin{array}{l}\text { Colleges and } \\
\text { universities of } \\
\text { technology }\end{array}$} & \multirow{3}{*}{$\begin{array}{c}\text { SE 70\%, } \\
\text { grammar 30\% }\end{array}$} & 5000 & \multirow{3}{*}{2.95} & 7.43 & 2.00 & 1.11 & 1.30 & \multirow{3}{*}{$\begin{array}{l}\text { Physical } \\
\text { education } \\
\text { college }\end{array}$} & \multirow{3}{*}{$\begin{array}{c}\text { Sports } 90 \%, \\
\text { grammar 10\% }\end{array}$} & 5000 & \multirow{3}{*}{1.85} & 1.78 & 1.93 & 11.04 & 1.35 \\
\hline & & 10,000 & & 6.33 & 1.71 & 1.37 & 1.25 & & & 10,000 & & 1.59 & 1.77 & 10.04 & 1.30 \\
\hline & & 20,000 & & 5.56 & 1.50 & 1.05 & 1.20 & & & 20,000 & & 1.36 & 1.62 & 9.12 & 1.27 \\
\hline \multirow{3}{*}{$\begin{array}{l}\text { Agriculture } \\
\text { and forestry } \\
\text { colleges }\end{array}$} & & 5000 & & 7.43 & 2.00 & 1.11 & 1.30 & & & 5000 & & 10.60 & 2.50 & 1.14 & 1.40 \\
\hline & $\begin{array}{l}\text { SE } 70 \%, \\
\text { grammar } 30 \%\end{array}$ & 10,000 & 2.84 & 6.33 & 1.71 & 1.37 & 1.25 & $\begin{array}{l}\text { Art colleges and } \\
\text { universities }\end{array}$ & Arts $100 \%$ & 10,000 & 10.28 & 7.77 & 2.10 & 1.11 & 1.30 \\
\hline & & 20,000 & & 5.56 & 1.50 & 1.05 & 1.20 & & & 20,000 & & 6.91 & 2.00 & 1.09 & 1.27 \\
\hline
\end{tabular}

Note: It is from the reference [51]. When the students scale is less or more than the scale values listed in the table, the indicators should use the minimum or maximum scale value in the table; when the student scale is between the listed scale values, the value of the insertion method should be used. Each quota does not include the value for postgraduate students. For art schools with a student scale of less than 2000 and with a wide range of professions, the indicators for classrooms and laboratories can be multiplied by an adjustment factor of 1.2-1.4. SE, science and engineering. 
Table 3. Subsidy area standard of laboratory and library for postgraduates (unit: $\mathrm{m}^{2}$ per student).

\begin{tabular}{cccc}
\hline Disciplines & Postgraduates & \multicolumn{2}{c}{ Subsidy Content } \\
\cline { 2 - 4 } & & Laboratory & Library \\
\hline $\begin{array}{c}\text { Engineering, science, agriculture and } \\
\text { forestry, medicine, art }\end{array}$ & Master & 6.0 & 0.5 \\
\cline { 2 - 4 } $\begin{array}{c}\text { Literature, foreign languages, economics, } \\
\text { law, management }\end{array}$ & Doctoral & 8.0 & 0.5 \\
\cline { 2 - 4 } & Master & 4.0 & 0.5 \\
\hline Normal arts, art design, sports & Doctoral & 6.0 & 0.5 \\
\cline { 2 - 4 } & Master & 4.0 & 0.5 \\
\hline
\end{tabular}

Note: It is from the reference [51].

\subsection{Surplus or Insufficient State of HERs' for Each College and University}

According to Equation (1), the HERs in HUEL, HUCM, NCUWREP and HAU all exceed the area quotas as shown in Figure 2, and there is spare available for other campuses. The remaining seven schools are deficient in some HERs (mainly of library and canteen). Libraries in HRTU, HUAHR and HFU, respectively, cover only $4 \%, 12 \%$ and $20 \%$ of the area quota value, and canteens in HIET, HP, HUAHR, respectively, cover only $38 \%, 49 \%$ and $49 \%$ of their area quota value, which is seriously inadequate. The area value of classrooms, laboratories and indoor sports rooms all exceed the standard quota. The classroom values of four schools (HUCM, HRTU, HFU and HAU) are more than three times that of the standard one. The laboratory values of four schools (HUEL, HRTU, HFU and HPC) are more than five times that of the standard one. The indoor sports room values of four schools (HUEL, HUCM, HAU and HPC) are more than two times that of the standard one.

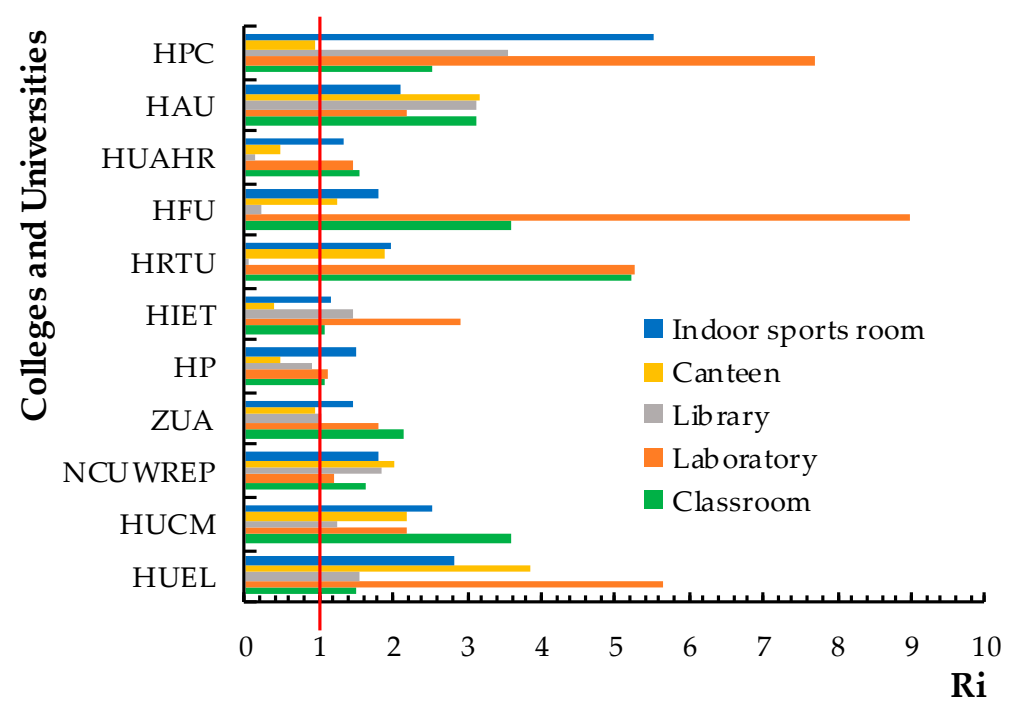

Figure 2. The rate over area quota $\left(\mathrm{R}_{\mathrm{i}}\right)$ for hardware educational resources (HERs) of each college and university in Longzi Lake University Town (UT). Note: HUEL, Henan University of Economics and Law; HIJPO, Henan Institute of Judicial and Police Officers; HUCM, Henan University of Chinese Medicine; NCUWREP, North China University of Water Resources and Electric Power; ZUA, Zhengzhou University of Aeronautics; HP, Henan Polytechnic; HIET, Henan Institute of Economics and Trade; HRTU, Henan Radio \& Television University; HFU, Henan Finance University; HUAHR, Henan University of Animal Husbandry and Economy; HAU, Henan Agricultural University; and HPC, Henan Police College. 


\subsection{The ISPHERs in Longzi Lake UT}

The area potential and student potential of shareable HERs are calculated by Equations (2) and (3), respectively. It is indicated from Figure 3 that the libraries allocation in four schools (HP, HRTU, HFU and HUAHR) are insufficient and need to be externally provided, the insufficient areas of which are $2659,24,946,12,580$ and $24,242 \mathrm{~m}^{2}$, respectively, and the unsatisfied numbers of students of which are 1705, 15,211, 6386 and 14,094, respectively. The canteens in five schools (ZUA, HP, HIET, HUAHR and HPC) need to be provided by the external campuses, the insufficient areas of which are 1766, 11,596, $18,453,10,230$ and $439 \mathrm{~m}^{2}$, respectively, and the unsatisfied numbers of students of which are 1471, $9664,14,304,8217$ and 348, respectively. In contrast, libraries and canteens in the other campuses have a relative surplus to lend assistance. The shareable area of all the libraries and canteens is accumulated by Equation (4)-126,074 and 176,332 $\mathrm{m}^{2}$, respectively. The shareable number of students among all libraries and canteens are accumulated by Equation (5) — 79,661 and 147,036, respectively.

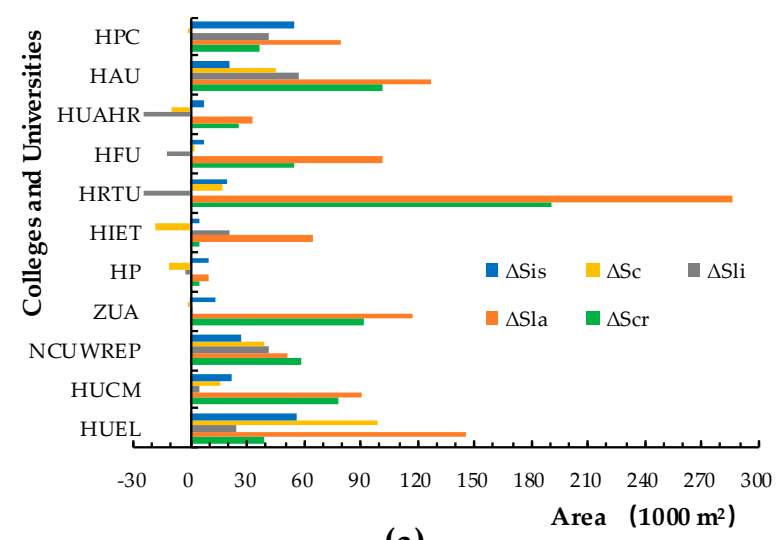

(a)

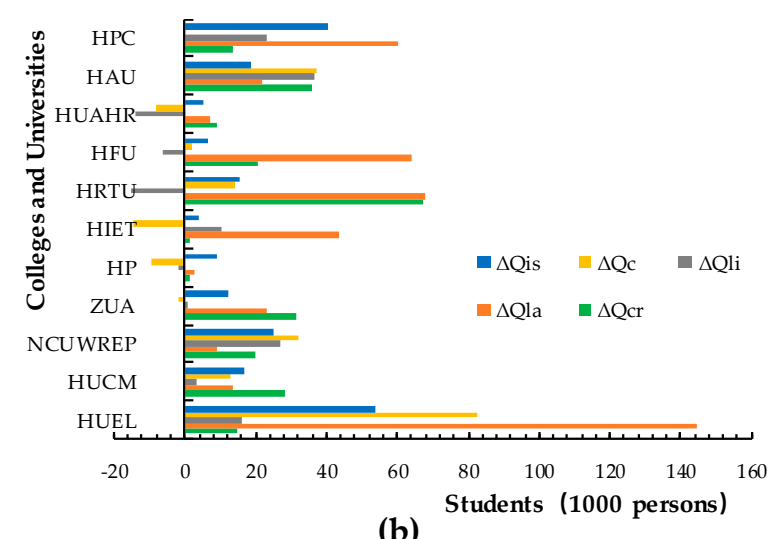

(b)

Figure 3. The area potential (a) and student potential (b) of sharable hardware educational resources (HERs) in Longzi Lake University Town (UT). Note: HUEL, Henan University of Economics and Law; HIJPO, Henan Institute of Judicial and Police Officers; HUCM, Henan University of Chinese Medicine; NCUWREP, North China University of Water Resources and Electric Power; ZUA, Zhengzhou University of Aeronautics; HP, Henan Polytechnic; HIET, Henan Institute of Economics and Trade; HRTU, Henan Radio \& Television University; HFU, Henan Finance University; HUAHR, Henan University of Animal Husbandry and Economy; HAU, Henan Agricultural University; and HPC, Henan Police College. $\Delta S_{\text {is }}$, the shareable area potential of indoor sports rooms; $\Delta S_{c}$, the shareable area potential of canteens; $\Delta \mathrm{S}_{\mathrm{li}}$, the shareable area potential of libraries; $\Delta \mathrm{S}_{\mathrm{la}}$, the shareable area potential of laboratories; $\Delta \mathrm{S}_{\mathrm{cr}}$, the shareable area potential of classrooms. $\Delta \mathrm{Q}_{\mathrm{is}}$, the student number potential of indoor sports rooms; $\Delta \mathrm{Q}_{\mathrm{c}}$, the student number potential of canteens; $\Delta \mathrm{Q}_{\mathrm{li}}$, the student number potential of libraries; $\Delta \mathrm{Q}_{\mathrm{la}}$, the student number potential of laboratories; $\Delta \mathrm{Q}_{\mathrm{cr}}$, the student number potential of classrooms. 
The three other kinds of HER in 11 schools are all richer and have excess. The accumulation values of the area potential for laboratories, classrooms and indoor sports rooms in the 11 campuses are $1,104,731,684,876$ and $242,635 \mathrm{~m}^{2}$, respectively. The accumulation value of the shareable student potential for those is $457,606,244,352$ and 208,023 , respectively. This means that if inter-campus sharing can be achieved without barriers, these five kinds of HER can not only satisfy these 11 colleges but also have surplus.

\subsection{The Sharable Potential Index in Longzi Lake UT}

The weights of HERs are determinated by the Delphi method [49]. After three rounds of scoring by 20 experts, the weights calculated by Equation (6) are 0.3135 for classrooms, 0.2039 for laboratories, 0.1994 for libraries, 0.2832 for canteens and 0.198 for indoor sports rooms, respectively. Equations (7) and (8) are used to calculate the sub-index and the comprehensive index, respectively, and the results are shown in the Table 4. The potential indexes of classrooms, laboratories and indoor sports rooms in campuses are all greater than 0 and with surplus. The potential index of libraries in $36.36 \%$ of campuses and that of canteen in $45.45 \%$ ofcampuses are less than 0 and need assistance from the other campuses.

Table 4. The potential index and potential grades in Longzi Lake University Town (UT).

\begin{tabular}{ccccccc}
\hline Colleges and Universities & $\mathbf{K}_{\mathbf{c r}}$ & $\mathbf{K}_{\mathbf{l a}}$ & $\mathbf{K}_{\mathbf{l i}}$ & $\mathbf{K}_{\mathbf{c}}$ & $\mathbf{K}_{\mathbf{i s}}$ & $\mathbf{K}$ \\
\hline HUEL & 0.34 & 0.83 & 0.36 & 0.74 & 0.65 & 0.69 \\
HUCM & 0.72 & 0.56 & 0.22 & 0.54 & 0.60 & 0.66 \\
NCUWREP & 0.38 & 0.22 & 0.46 & 0.50 & 0.44 & 0.49 \\
ZUA & 0.53 & 0.45 & 0.04 & -0.06 & 0.31 & 0.31 \\
HP & 0.07 & 0.11 & -0.10 & -1.04 & 0.33 & -0.20 \\
HIET & 0.07 & 0.65 & 0.31 & -1.65 & 0.15 & -0.22 \\
HRTU & 0.81 & 0.81 & -22.08 & 0.47 & 0.50 & -3.75 \\
HFU & 0.72 & 0.89 & -3.96 & 0.19 & 0.45 & -0.24 \\
HUAHR & 0.36 & 0.31 & -7.39 & -1.06 & 0.25 & -1.55 \\
HAU & 0.68 & 0.56 & 0.68 & 0.69 & 0.52 & 0.76 \\
HPC & 0.60 & 0.87 & 0.72 & -0.04 & 0.82 & 0.66 \\
\hline
\end{tabular}

Note: HUEL, Henan University of Economics and Law; HIJPO, Henan Institute of Judicial and Police Officers; HUCM, Henan University of Chinese Medicine; NCUWREP, North China University of Water Resources and Electric Power; ZUA, Zhengzhou University of Aeronautics; HP, Henan Polytechnic; HIET, Henan Institute of Economics and Trade; HRTU, Henan Radio \& Television University; HFU, Henan Finance University; HUAHR, Henan University of Animal Husbandry and Economy; HAU, Henan Agricultural University; and HPC, Henan Police College. $\mathrm{K}_{\mathrm{cr}}$, the potential index for classrooms; $\mathrm{K}_{\mathrm{la}}$, the potential index for laboratories; $\mathrm{K}_{\mathrm{li}}$, the potential index for libraries; $\mathrm{K}_{\mathrm{c}}$ the potential index for canteens; $K_{i s}$, the potential index for indoor sports rooms; $K$, the comprehensive index.

According to Table 4 and Figure 4, six campuses with excess shareable potential belong to level I, which accounts for $54.55 \%$ of the total. Among them, HUEL, HUCM, HAU and HPC are level I-ii, reaching $36.36 \%$ of the total. The canteen's potential index of HPC is less than 0 , but those of the rest of the school buildings are high, so it is relatively high as a whole. The grades of NCUWREP and ZUA are I-iii and II-iv, respectively. The campuses with a comprehensive potential index less than 0 account for $45.45 \%$ of the total. Due to the serious shortage of libraries, the grades of HRTU and HUAHR are III-v, those of HIET and HFU are III-ii, and that of HP is III-i. 


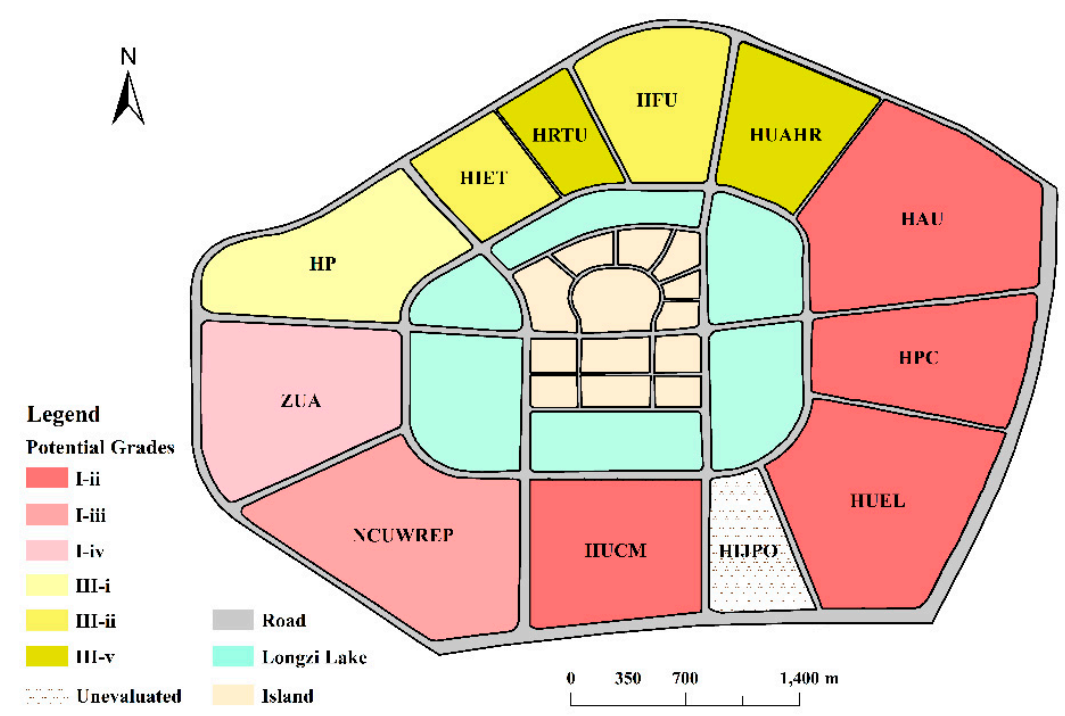

Figure 4. Grades of inter-campus sharable potential of HERs (ISPHERs) in Longzi Lake University Town (UT).

\section{Discussion}

\subsection{Characteristics of ISPHERs in Longzi Lake UT}

As shown in Figure 4, the comprehensive value of ISPHERs is high in the south and low in the north as a whole. The colleges and universities with a long history and dominated by undergraduate education are generally higher than those with vocational skills training or upgrading from junior college to undergraduate ones. This is because the southern colleges and universities entered Longzi Lake UT earlier as a whole, paid more attention to the infrastructure construction, and the school buildings are relatively perfect, such as in NCUWREP and HUEL. On the other hand, the students' number of colleges and universities focusing on vocational skills training has increased rapidly in recent years, and some school buildings are relatively scarce, such as HRTU. There are also a merger of schools and a shortage of infrastructure, such as HFU and HUAHR. Under this condition, sharing HERs among campuses is particularly important.

In addition, the focus of colleges and universities also has an impact on the amount of HERs. For example, HRTU pays more attention to distance learning based on information technology, and students are more mobile, so they will rely less on libraries and canteens. Meanwhile, for these large teaching buildings, the investment is huge, the construction period is very long, so some schools, mainly relating to vocational education, do not attach great importance to them. It is suggested that the influence of different teaching models should be considered in the Standard 191-2018 [51]. Taking libraries as an example, which are more and more dependent on modern information technology, the area standard should be appropriately reduced.

Because no one has studied the sharing potential of HERs in this region and others before, it is difficult to put forward the contrast of results. It is suggested that HRTU, HUAHR, HIET, HFU and HP with insufficient HERs should consciously choose possibly sharable sources nearby. For example, the surplus library of HAU, after providing resources to HFU and HUAHR, still has a surplus of 20,100 $\mathrm{m}^{2}$. For campuses with rich resources potential, such as HUEL, HUCM, HAU, and HPC, in addition to providing some resources to the other campuses, they also should pay more attention to their overall planning and development. Since most of them in the Longzi Lake UT are new campuses and there are one or more campuses elsewhere, multi-campus joint schools will be implemented for a long time. Therefore, it is necessary to make clear the development orientation and functional zoning of each campus [52,53], reasonably allocate the student population, and improve the intensive utilization of educational land resources and HERs. Their future intensive utilization status might be changed with 
the reconstruction of school buildings or the enrollment plan. Therefore, the dynamic changes in ISPHERs in Longzi Lake UT should be monitored subsequently.

\subsection{Implications for Guarantee System}

In order to break the "wall" between colleges and universities, we should pay full attention to the mutual demand and independence of colleges and universities, and establish a scientific and effective coordination and management system (Figure 5). First, the sustainable concept of cooperative learning and open school should be set up, in which educational land resources and HERs of the campuses are integrated, and the intensive sharing and sustainable use of resources is one of the main goals $[13,41]$. Second, the HER Sharing Committee of a UT should be established to take planning and management measures of HER sharing. The personnel should comprise the government officer of the UT, heads of colleges and universities and relevant technical experts $[6,28,31]$. Third, to improve the efficiency of land utilization, the campus planning should conform to the overall planning of the city and the other construction standards [54]. For sharing the large and medium-sized teaching facilities with high demands (i.e., laboratory, indoor sports room, hall), to avoid waste or repeated construction, they should be centralized and unified in their management $[55,56]$. Then, the sharing of HERs will be promoted by interest adjustments such that the intensive use of educational land resources and HER sharing are brought into the administrative management and evaluation systems. Finally, there are some technological measures, such as establishing technology platform of cooperation sharing, setting up special sharing funds, and running school buses to ensure the inter-campus sharing $[14,36]$. Only in this way can we combine all the sharing units in a UT, run the sharing interface, improve the sharing environment and effect, optimize the sharing mode, and finally form a sustainable development system of HER sharing.

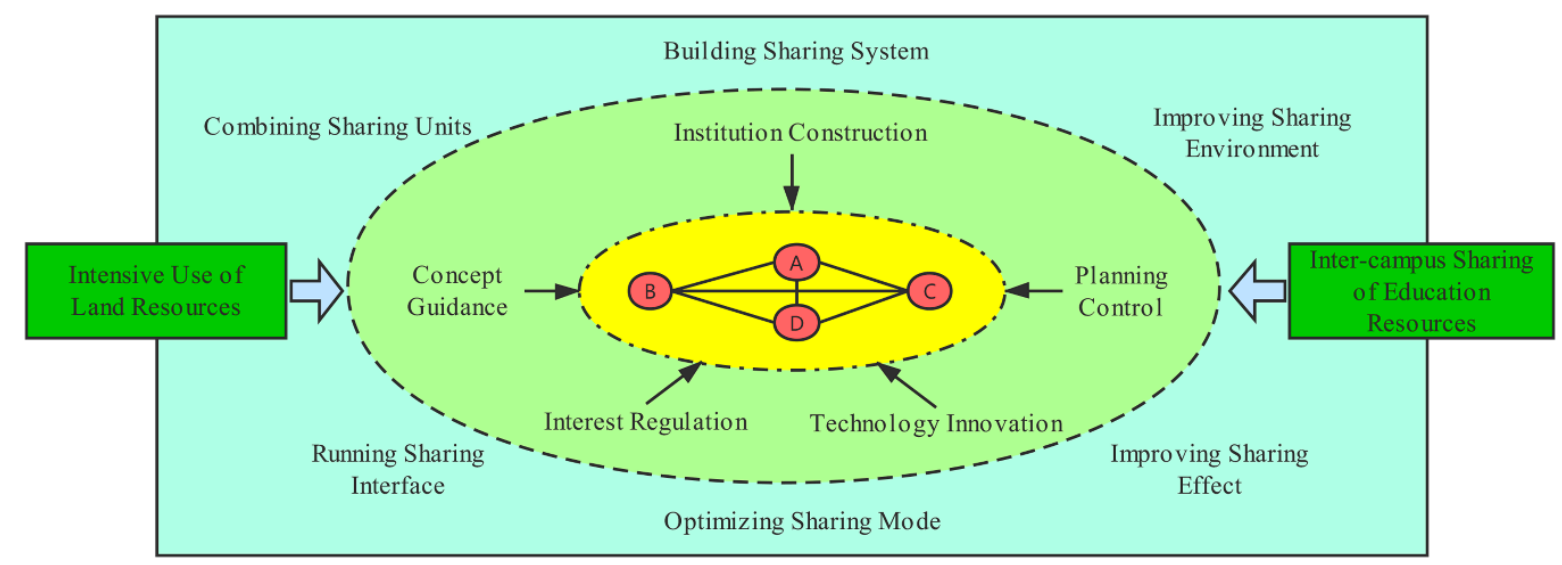

Figure 5. A sustainable security framework for inter-campus sharing of hardware educational resources (HERs) in a University Town (UT). Note: A, B, C and D are sharing units, which are colleges and universities.

\subsection{Recommendations for Future Study}

The evaluation of the intensive utilization of educational land resources has become more and more mature in China in recent years [45,57]. Based on the correlation of educational land resources utilization and HER sharing, defining the connotation of ISPHERs and determining its quantitative approach are theoretically and methodologically feasible. In the choice of area quota, different regions and schools may be different, but in the same region, the standards of the same kind of institution can be unified. The school classification is an important factor in determining the area quota. For example, the laboratory area quotas of finance, policy and law colleges in the reference [51], is only from $18.17 \%$ to $28.36 \%$ of those in comprehensive, technology, agriculture and forestry colleges. Many colleges and universities are gradually developing into comprehensive universities, so disciplines and enrollment 
will have some of the following changes. The laboratory shareable index of HUEL, HRET, HFU and HPC is as high as $0.83,0.81,0.89$, and 0.87 according to the financial and political law standards. According to the standards of comprehensive colleges and universities, this will be greatly reduced. The school classification is based on the proportion of the student population taking different subjects in the Standard 191-2018 [51]. Because of the influence of the adjustment of professional enrollment and other factors, there will be some fluctuation in ISPHERs, and the data analysis with long time sequence needs to be carried out in the future. Meanwhile, the classification of colleges and universities is advised to consider other standards, such as by professional proportion, funds input or output of scientific researches, etc. [58,59]. In addition, some colleges and universities in some UTs have a long construction period, a low degree of land resource development and utilization, and have a large stock of educational land resources now. According to the contrast of current building density, plot ratio with land quota and development planning, we can further determine the future ISPHERs and the comprehensive grades. This will be an important reference for the joint sustainable development of educational land resources and HERs in UTs.

\section{Conclusions}

The imbalance of supply and demand of ERs is quite common in some UTs. This is not conducive to the resources' intensive utilization and the UTs' sustainable development. Sharing ERs among adjacent campuses can solve or alleviate this problem to a degree. For the competitive HERs with land resources as carriers, the key to inter-campus sharing is whether there is potential for resources sharing.

Based on the relationship between the intensive use of educational land resources and HERs' sharing in a UT, this paper firstly defines the connotation of ISPHERs from the perspective of "the best utilization degree" which mainly depends on the utilization and development gap between the present area value and the possible most intensive one under certain conditions. Based on the area quota and the student's number, the ISPHERs can be calculated by the Delphi and multi-factor model methods. Taking Longzi Lake UT in Zhengzhou City, Henan province, China as the study area, the shareable potential of five HERs (i.e., classroom, laboratory, library, indoor sports room and canteen) in 11 colleges and universities is calculated. It shows that the overall shareable potential is high in the south and low in the north. The HERs such as libraries and canteens in HP, HIET, HRTU, HFU and HUAHR, which are mainly based on vocational skills training, are insufficient. These five HERs in four campuses (i.e., HUEL, HUCM, NCUWREP and HAU) are abundant. If 11 universities are accessible to share HERs, these five HERs are all surplus as a whole.

Compared with software educational resources' sharing, HER sharing is more difficult if there is not an effective guarantee system. Therefore, we should follow the principle of being independent and complementary to each other in a UT, and fully unite governments, colleges and universities and the public. Only by the multi-pronged measures of sustainable concept guidance, system construction, planning control, interest adjustment and technological innovation, might the inter-campus sharing of HERs in UTs be realized smoothly.

Compared to other studies, this paper firstly defines the connotation of ISPHERs and determines its quantitative approach, which can extend the scope of the intensive utilization of educational land and deepen the research on symbiotic theory in education ecosystem. Furthermore, it can identify the donor and acceptor of HER inter-campus sharing, and provide a management basis for the supply and allocation of HERs. As a result, it will both improve the degree of intensive utilization of educational land resources and HERs, and greatly promote the sustainable development in a region with centralized campuses.

Author Contributions: Y.Z. and H.Z. conceived and designed the experiment; B.M., and X.Z. helped the data analysis and the paper revision; X.C. helped the language correction; Y.Z. wrote the paper. All authors have read and agreed to the published version of the manuscript.

Funding: This work was financially supported by Henan Social Science Planning Project (No.: 2017BJJ035); the 13th five-year Plan of Educational Science in Henan Province (No.: 2018-JKGHYB-0035); the National Nature 
Science (No.: 51808198); the Humanities and Social Science Research Project of Henan Education Department (No.: 2017-ZZJH-230) and the Research and practice Project of higher Education Teaching Reform in Henan Province (No.: 2017SJGLX241).

Conflicts of Interest: The authors declare no conflict of interest.

\section{References}

1. Feichtinger, T.; Niedanfeichtinger, S. Assessing regional sustainable development through an integration of nonlinear principal component analysis and Gram Schmidt orthogonalization. Ecol. Indic. 2016, 63, 71-81. [CrossRef]

2. Wariah, S.S.; Karthikeyan, K. Trends in higher education and growth in India: A case study. J. Phys. Confer. Ser. 2018, 1139, 012033. [CrossRef]

3. Ou, D.; Hou, Y. Bigger pie, bigger slice? The impact of higher education expansion on educational opportunity in China. Res. High. Educ. 2019, 60, 358-391. [CrossRef]

4. Zhao, L. Analysis of resource shareable based on university city mode. Course Educ. Res. 2015, 1, 1-11. [CrossRef]

5. Shi, M.H.; Yao, W.X.; Liu, B. Discussion on the shareable of teaching resources in university city: A case study of Shanghai Songjiang university town. Text. Appar. Educ. 2014, 29, 233-235. [CrossRef]

6. Pounds, A.; Bostock, J. Open educational resources (OER) in higher education courses in aquaculture and fisheries: Opportunities, barriers, and future perspectives. Aquacult. Int. 2019, 1, 695-710. [CrossRef]

7. Kwak, S. How korean language arts teachers adopt and adapt open educational resources: A study of teachers' and students' perspectives. Int. Rev. Res. Open. Dis. 2017, 18, 193-211. [CrossRef]

8. Karen, H.Q.; Rhona, S.W.; Gail, K.; Harold, L.; Frank, C.W. University-partnered new school designs: Fertile ground for research-practice partnerships. Edu. Res. 2017, 46, 143-146.

9. Marjorie, L.D.-W.; Christopher, S. Conducting comprehensive assessment within community colleges: Administrative, educational, and student support (AES) assessment with the shults Dorimé Williams taxonomy. New Dir. Commun. Coll. 2019, 186, 61-69. [CrossRef]

10. Wey, W.M.; Hsu, J. New urbanism and smart growth: Toward achieving a smart national taipei university district. Habitat. Int. 2014, 42, 164-174. [CrossRef]

11. Ye, C.; Chen, M.; Chen, R.; Guo, Z. Multi-scalar separations: Land use and production of space in Xianlin, a university town in Nanjing, China. Habitat Int. 2014, 42, 264-272. [CrossRef]

12. Zhang, X.L.; Tang, A.G. Independence and share: Target of movement and channel about city town. Res. Educ. Dev. 2002, 5, 12-15. [CrossRef]

13. Friedman, H.H.; Kass, F. How the city university of New York (CUNY) can improve efficiency, reduce waste, and save millions? Soc. Sci. Electron. Publ. 2018. [CrossRef]

14. Lu, T.J.; Buehler, R.; Mondschein, A.; Hankey, S. Designing a bicycle and pedestrian traffic monitoring program to estimate annual average daily traffic in a small rural college town. Transp. Res. Part D Transp. Environ. 2017, 53, 193-204. [CrossRef]

15. Kirby, W.C. The Chinese century? The challenges of higher education. Daedalus 2014, 143, 145-156. [CrossRef]

16. $\mathrm{Li}, \mathrm{C} . ; \mathrm{Xu}, \mathrm{Z}$. The study on the intensive use of land resources in the process of new urbanization. IOP Conf. Ser. Earth Environ. Sci. 2017, 100, 012169. [CrossRef]

17. Yeo, I.A.; Dobson, K.; Josso, P.; Pearce, R.B.; Howarth, S.A.; Lusty, P.A.J. Assessment of the mineral resource potential of atlantic ferromanganese crusts based on their growth history, microstructure, and texture. Minerals 2018, 8, 327. [CrossRef]

18. Aseres, S.A. Assessment of the potentials tourism resources of choke mountain and its environs, Ethiopia. J. Tour. Hosp. 2015, 4, 2. [CrossRef]

19. Mugagga, F.; Nabaasa, B.B. The centrality of water resources to the realization of sustainable development goals (SDG). a review of potentials and constraints on the African continent. Int. Soil Water Conserv. Res. 2016, 4, 215-223. [CrossRef]

20. Koohafkan, A.P. Land resources potential and sustainable land management: An overview. Nat. Resour. Forum 2010, 24, 69-81. [CrossRef]

21. Marcus-Quinn, A. The potential of high-quality open educational resources (oers) for the teaching of english poetry. J. Poetry Ther. 2016, 29, 33-45. [CrossRef] 
22. Song, J. The digital way to develop the resources potential of migrant workers' continuing education, based on the analysis of the current situation of migrant workers' readers. Publ. Res. 2014, 12, 85-88. [CrossRef]

23. Mutual Selection of Courses and Mutual Recognition of Credits of Five Universities in Henan. Available online: http://www.chinanews.com/sh/2019/01-09/8723721.shtml (accessed on 21 February 2020).

24. Brockliss, L. Gown and town: The university and the city in Europe, 1200-2000. Minerva 2000, 38, 147-170. [CrossRef]

25. Ngo, L.M.; Trinh, T.A. A university-city complex, a model for sustainable development: A case study in Vietnam. Procedia Eng. 2016, 142, 92-99. [CrossRef]

26. Woldoff, R.A.; Weiss, K.G. Studentification and disorder in a college town. City Commun. 2018, 4. [CrossRef]

27. Mayfield, L. Town and gown in America: Some historical and institutional issues of the engaged university. Educ. Health Chang. Learn. Pract. 2001, 14, 231-240. [CrossRef]

28. Harris, M.S. The soft underbelly of universities as anchor institutions: The disconnect between university and community research priorities. High. Educ. Policy 2019, 2. [CrossRef]

29. Brandt, C.; de Mortanges, C. City branding: A brand concept map analysis of a university town. Place Brand Publ. Dipl. 2011, 7, 50-63. [CrossRef]

30. Moore, J.G. Mississippi College Towns: Assessing the Geography of Collegiate Culture. Master's Theses, University Southern Mississippi, Hattiesburg, MS, USA, May 2016.

31. Hooker, B.; Small, E.; Dizard, J.; Darlington, S.; Farnham, T.; Benkley, J. Five College Blue Sky Report. 2012. Available online: https://scholarworks.umass.edu/cgi/viewcontent.cgi?article=1002\&context=csi (accessed on 21 February 2020).

32. Li, Z.; Li, X.; Wang, L. Speculative urbanism and the making of university towns in China: A case of Guangzhou university town. Habitat Int. 2014, 44, 422-431. [CrossRef]

33. Tlili, A.; Huang, R.; Chang, T.-W.; Nascimbeni, F.; Burgos, D. Open educational resources and practices in China: A systematic literature review. Sustainability 2019, 11, 4867. [CrossRef]

34. Jing, L. Constructing resource sharing collaboration for quality public education in urban china: Case study of school alliance in beijing. Int. J. Educ. Dev. 2018, 59, 9-19. [CrossRef]

35. Halachmi, A.; Ngok, K. Of sustainability and excellence: Chinese academia at a crossroads. Publ. Adm. Rev. 2009, 69, S13-S20. [CrossRef]

36. Guan, M.H. Shareable university assets of university resource planning theory: A case study of Fuzhou university town. J. Minjiang Univ. 2016, 6, 114-120. [CrossRef]

37. Li, Z.H. Research on the Cooperative development and shareable of foreign journal resources in higher education mega center: Taking fuzhou higher education mega center as an example. J. Acad. Libr. 2012, 6, 71-75. [CrossRef]

38. Chen, P. Theoretical ideas and policy suggestions on college sports resource integration: A case study on Chongqing university town. J. Beijing Sport Univ. 2016, 39, 87-93.

39. Zhang, X.M. Study on the influencing factors of the shareable of sports field resource in Chinese university City based on factor analysis. J. Guangzhou Sp. Univ. 2015, 2, 120-122. [CrossRef]

40. Montgomery, C. Transnational partnerships in higher education in China: The diversity and complexity of elite strategic alliances. Lond. Rev. Educ. 2016, 14, 70-85. [CrossRef]

41. Li, X.; Roberts, J.; Yan, Y.; Tan, H. Knowledge shareable in China-UK higher education alliances. Int. Bus. Rev. 2014, 23, 343-355. [CrossRef]

42. Hu, D.; Luo, A.; Liu, H. Open access in China and its effect on academic libraries. J. Acad. Libr. 2013, 39, 110-112. [CrossRef]

43. Nie, Z.M.; Liu, Z.Y. The reform of quality education resource shareable system: From bureaucracy to communalization. J. Chin. Soc. Educ. 2017, 5, 56-61.

44. Ngok, K. Massification, bureaucratization and questing for "world-class" status: Higher education in China since the mid-1990s. Int. J. Educ. Manag. 2008, 22, 547-564. [CrossRef]

45. Wu, J.; Yuan, Y.; Wang, Y.H.; Yang, Z.Z. Evaluation on the intensive use of higher education land with multiple perspectives: A case study of shandong province. China Land Sci. 2018, 32, 67-74. [CrossRef]

46. The Land Administration Law of the People's Republic of China. Available online: http://www.sohu.com/a/ 338926400_120209902 (accessed on 21 February 2020).

47. Tan, S.K.; Zhou, M. Response of universities in Wuhan to the intensive land use policy. Resour. Sci. 2012, 34, 143-149. 
48. Ruoppila, S.; Zhao, F. The role of universities in developing China's university towns: The case of Songjiang university town in Shanghai. Cities 2017, 69, 56-63. [CrossRef]

49. Zhu, Q.; Jia, T.D.; Fei, M.; Wu, K.; Sun, X. Using a Delphi method and the analytic hierarchy process to evaluate Chinese search engines. Online Inf. Rev. 2013, 35, 942-956. [CrossRef]

50. Longzi Lake University Town. Available online: https://baike.so.com/doc/5576982-5790671.html (accessed on 21 February 2020).

51. Building Area Index of Ordinary Colleges and Universities (191-2018). Available online: https://wenku. baidu.com/view/aac3f66bdc36a32d7375a417866fb84ae45cc397.html (accessed on 21 February 2020).

52. Premchand-Mohammed, S. Bridging the gap between print and electronic resources at a multi-campus university library. Vine 2011, 41, 315-333. [CrossRef]

53. King, C.J. On the Apportionment of Administrative Governance Functions within Multi-Campus Universities and University Systems. Research \& occasional paper series: Cshe.16.13; 2013. Available online: https://eric.ed.gov/?id=ED545189 (accessed on 21 February 2020).

54. Nie, Z.; Zurlo, F.; Camussi, E.; Annovazzi, C. Service ecosystem design for improving the service sustainability: A case of career counselling services in the Italian higher education institution. Sustainability 2019, 11, 1427. [CrossRef]

55. Lippincott, J.K. New library facilities: Opportunities for collaboration. Resour. Shareable Info. Netw. 2004, 17, 147-157. [CrossRef]

56. Schwanz, K. Thinking about a joint-use library? Coll. Res. Libr. News 2019, 61, 478-482. [CrossRef]

57. Wang, Y.B.; Hu, Y.L.; Mi, C.L.; Song, Q.Q.; Liu, J.H.; Jin, J. Research on intensive use evaluation for university education land based on GIS and FAHP. J. Anhui Norm. Univ. Nat. Sci. 2017, 40, 167-173. [CrossRef]

58. Phusavat, K.; Ngavej, C.C. The role of university classification on developing standards in education. Int. J. Manag. Educ. 2007, 1, 318. [CrossRef]

59. Phusavat, K.; Ketsarapong, S.; Ranjan, J.; Lin, B. Developing a university classification model from performance indicators. Perform. Meas. Metr. 2011, 12, 183-213. [CrossRef]

(C) 2020 by the authors. Licensee MDPI, Basel, Switzerland. This article is an open access article distributed under the terms and conditions of the Creative Commons Attribution (CC BY) license (http://creativecommons.org/licenses/by/4.0/). 